\title{
Transfer Control of Public Housing Ownership in Indonesia
}

\author{
Muhammad Jibril ${ }^{1}$, Alexandra Geradina Maretta ${ }^{2}$ \\ ${ }^{1}$ Faculty of Law Universitas Gadjah Mada, muhjibril.law@gmail.com \\ 2 Faculty of Law Universitas Gadjah Mada, alexandrageradina@gmail.com
}

\begin{abstract}
Introduction to The Problem: Resettlement/Shelter is one of the basic human needs and plays a strategic role as the formation of character as well as national personality. However, there is still a problem concerning the availability of public housing in Indonesia. The root of this problem is because people are free to transfer their ownership over their public housing, which leads to the escalation of public housing price. One of the situations where an escalation of public housing price occurred and inaccurate-ownership is in Kalibata City. Kalibata City was supposed to be public housing, but in the present, it 3is occupied by upper-middle-income families as well as an investor.
\end{abstract}

Purpose/Objective Study: The purpose of this research article is to observe, analyze, and criticize the transfer of public housing ownership in Indonesia and provide a comparison with the Community Land Trust in the United States of America.

Design/Methodology/Approach: The research method employed in this research article is normative research method, whereas the types of data utilized are literature studies. The literature studies comprise of various sources in the form of laws, books, and journals related to public housing. The data is analyzed by employing a qualitative method and presented descriptively.

Findings: The result of this research article indicates that the Government Regulation which is a follow-up to Article 55 paragraph (5) Law Number 1 of 2011 regarding Housing and Resettlement Area which mandates to regulate further related to the appointment and establishment of the institution has not been formed yet. Furthermore, to realize intergenerational justice, the transfer institution must be burdened with specific duties.

Paper Type: Research Article

Keywords: Public Housing Ownership; Transfer Control; Intergenerational Justice

\section{Introduction}

The ideal foundations for Indonesia's national law development are Pancasila and the 1945 Constitution of the Republic of Indonesia. The values of Pancasila as already embedded in the TAP MPRS (i.e., The People's Representative Assembly Decree) No. XX/MPR/1966 is essentially a way of life, consciousness, and legal ideals and noble moral ideals which include psychological atmosphere, as well as the character of the Indonesian nation (Leks et al., 2013). As per stipulation of the fifth notion of Pancasila, namely "Social justice for the whole nation of Indonesia" is closely related to the state's obligation to regulate people's housing (Leks et al., 2013), which firmly embedded in the 1945 Constitution of the Republic of Indonesia. 


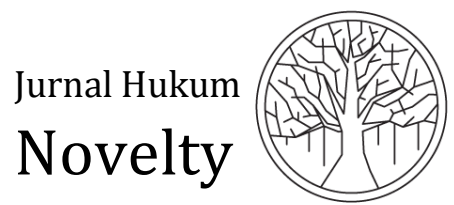

Volume 10, Issue 01, 2019, pp. 23-33

P-ISSN: 1412-6834 E-ISSN: 2550-0090

Fulfillment of people rights to acquire housing is one of the state's goals that listed in the preamble of the 1945 Constitution of the Republic of Indonesia that is "to promote public welfare." The parameter to access such goal has fulfilled from the quality and quantity of housing obtained by society (Leks et al., 2013). Article $28 \mathrm{H}$ paragraph (1) of the 1945 Constitution of the Republic of Indonesia stipulates that every person shall have the right to live in physical and spiritual prosperity to have a home and to enjoy a well and healthy environment, and shall have the right to obtain medical care. In an international context, those rights are regulated strictly in Article 11 International Covenant on Economic and Social Council (ECOSOC) which Indonesia has ratified it on 28 October 2005, which states:

The States Parties to the present Covenant recognize the right of everyone to an adequate standard of living for himself and his family, including adequate food, clothing, and housing, and to the continuous improvement of living conditions. The States Parties will take appropriate steps to ensure the realization of this right, recognizing to this effect the essential importance of international co-operation based on free consent.

Under the abovementioned provision, the Indonesia government then enacted the Act of Housing and Resettlement Area No. 1 of 2011 as legal basis and guidance in governing concerning housing in Indonesia.

Ideally speaking, every family must be provided with housing as it is one of the basic human needs (Arimurthy \& Manaf, 2013), which is constitutionally guaranteed, especially for low-income families. A home not only provides protection from physical elements but also holds social and psychological benefits and serves as a potential source of self-identity, security, and social status (Motley \& Perry, 2012).

Around the globe, government-subsidized low-income housing programs have come under renewed scrutiny (Vale, 1995). However, due to the limited number of land in Indonesia, either in an urban or rural area, accompanied with the increase of infrastructure development and also the expansion of population, leads to the imbalance between supply and demand of land. Managing the gap between housing supply and demand is a challenge for city and country housing agencies (Toros \& Flaming, 2018).

The imbalance between supply and demand triggers the escalation of land price, which is to set the price for housing and resettlement area. Skyrocketing housing prices and the loss of affordable housing are becoming increasingly acute problems for low-income households (Huang, 2012). The data from Directorate General of Housing Provision Ministry of Public Works and Public Housing in 2016 informed that there were as many as 7.6 million people in Indonesia that lived in a non-feasible house and the demand for a new house was up to 800.000 per year (Tim Komunikasi Publik Ditjen Penyediaan Perumahan, 2016) 
Based on the data from Directorate General of Housing Provision above, the most struggling one to own land is lower-middle-income families. Several efforts have been made by the government to fulfill the needs of those housing, especially for public housing. One of it is by holding One Million Houses Program, which around 603.000 houses from that one million are intended for low-income families (Direktorat Jenderal Anggaran Kementrian Keuangan, 2015). Public housing is housing provided for low-income families, which improves physical living conditions, reduces residential mobility, and enables families to spend more of their income on items that benefit children's development (Newman \& Harkness, 2002).

Government has specific actions towards low-income families in housing matters, which regulated in the act of Housing and Resettlement Area No. 1 of 2011. Those actions incorporated in the Act are building and helping low-income families to acquire public housing in the form of ease of financing, infrastructure development, public utility, permit cost aid, stimulant aid, and fiscal incentive. The government also stipulated particular prohibitions as a means to help low-income families; one of them is the prohibition in transferring the ownership of public housing.

Article 135 of this Act states that every person is prohibited from renting or transferring their ownership of public housing to another party. The transfer of ownership is only allowed by a particular condition based on Article 55 of Law No. $1 / 2011$, that is if the transfer is carried out by an institution that is appointed or established by the Government or Regional Government, which is further regulated by a Government Regulation. On the contrary, the government regulation that is mandated by this Act has not been issued. Therefore, there will be a legal gap for lowincome families to transfer their public housing ownership due to the absence of this transfer institution.

Assuming that things are maintained like this, Kalibata City case will undoubtedly reoccur. Kalibata City is public housing that is intended for low-income families. However, the fact is that public housing is occupied by middle-income families, highincome families, and also property investor (Yudis, 2015). Based on the fact described above, the problems that need to be analyzed further are: 1) How is the regulation on transfer of public housing ownership based on Indonesia positive law? 2) How to provide affordable and sustainable housing for future generations of low-income families to accomplish intergenerational justice?

\section{Methodology}

The research method employed in this research article is normative research, whereas the research material used is only secondary data. The secondary data is obtained through literature studies of various sources in the form of laws, books, and journals (Soekanto \& Mamudji, 2007). The data is then analyzed by employing a qualitative method and presented in a narrative form. In this research, there is an 
effort to record, analyze, describe, and interpret the current status quo; in other words, this research is aiming to gain information about the fact in concreto.

According to the research method, there are some approaches used, such as statute approach, historical approach, and comparative approach. Statute approach is made by examining all of the regulation related to public housing in Indonesia. The historical approach is meant to examine the development of regulation that regulates the transfer of public housing in Indonesia. The comparative approach is conducted by comparing public housing in Indonesia and the United States of America

\section{Analysis and Results}

\section{The provision regarding Transfer of Public Housing Ownership in Indonesia}

In the housing and resettlement sector development, the government is responsible for formulating and setting policies and national strategies (Article 13 Law No.1/2011). Furthermore, it also has the authority to formulate and perfect regulations (Article 16 Law No. 1/2011). Thus, various kinds of regulations have been issued related to the implementation of housing for low-income families (Leks et al., 2013), one of which is Law No 1/2011. The restriction on the transfer of public housing ownership is stipulated in Article 55 paragraph (2) Law No.1/2011 as follows:

"Individuals who own public housing with facilities provided by the Government or the regional government can only rent or transfer their ownership of the house to other parties, in terms of:
a. inheritance;
b. occupancy after at least 5 (five) years; or
c. moving residence because of a better socio-economic level."

On the other hand, Article 135 Law No. 1/2011 prohibits homeowners from renting or transferring their ownership of public housing to other parties. As stated in Article 150 paragraph (1), violations of Article 135 can be subject to administrative sanction. Also, in the criminal act provisions of Article 152 of the Law No. 1/2011 stated that every person who rents or transfers his ownership of a public house to another party as referred to in Article 135 should be liable to a fine of not exceeding Rp50.000.000,00 (five million rupiahs). It then implies that public homeowners who rent or transfer their ownership of public housing not following the provisions contained in Article 55 paragraph (1) may be subject to administrative or criminal sanctions.

Furthermore, Article 55 paragraph (2) of Law No. 1/2011 states that the transfer of public housing ownership as referred to in Article 55 paragraph (1) letters b and c, must be carried out by an institution appointed or established by the Government or Regional Government in the housing and resettlement area sector. Provisions regarding the appointment and establishment of the institution by the Government or Regional Government based on Article 55 paragraph (5) will be regulated further 
under Government Regulation. According to Maria Farida, Government Regulations must implement the provisions within a Law which explicitly requests to be further regulated in a Government Regulation (Indrati, 1998).

If it is grammatically interpreted, Government Regulation shall be issued in order to provide clarity related to the appointment or establishment by Government or Regional Government on the institution that carries out the transfer. However, Article 46 of Government Regulation No 14 of 2016 concerning the Implementation of Housing and Settlement Areas (GR No. 14/2016) has regulated the related transfer institution:

"If ownership is transferred as referred to in Article 44 and Article 45, the transfer must be carried out by an institution appointed or established by the Government or Regional Government in the Housing and Resettlements Area sector."

Article 44 and Article 45 contains a further explanation of what is stated in Article 55 paragraph (1) letters b and c of Law No. 1/2011. Based on the Article, it can also be observed that Article 46 regulates further relating to the institutions as stated in Article 55 paragraph (5) of the Law No. 1/2011. If we look carefully at the consideration of Government Regulation Number 14 of 2016, it does not explicitly mention Article 55 paragraph (5) of the Law No. 1/2011 as a consideration. It has a juridical implication that the Government Regulation is not an implementing regulation of Article 55 paragraph (5) of the Law No. 1/2011. Therefore, Government Regulation that functions as a follow-up Article 55 paragraph (5) has not been issued yet.

Although GR No. 14/2016 does not constitute implementing regulations of Article 55 paragraph (5) of the Law No.1/2011, this does not result in Article 46 of the Government Regulation a quo to be not valid. Primarily, the Government and the Regional Government does not obtain the authority to appoint or establish a transfer institution from Article 46 of the GR No. 14/2016, but the authority is obtained from Article 55 paragraph (2) of the Law No. 1/2011. The juridical implication is that the Government and Regional Government can still appoint or establish a transfer institution, but there is no standard regulation related to the method of this appointment and establishment of the institution.

According to the Explanation of Article 55 paragraph (2) Law No.1/2011, a transfer institution plays a role in implementing distribution and delegation/transfer of public housing obtained by low-income families. It denotes that the public housing will be distributed to the eligible low-income families following the requirements to be convenient in owning/occupying in public housing.

In the absence of a transfer institution of public housing, there will be some possible impacts. First, the allocation of public housing for low-income families will be hampered. Due to the inexistence of the establishment of a public housing transfer 
institution, the low-income families who are eligible to rent/transfer public housing because they have fulfilled the provisions under Article 55 paragraph (2) Law No.1/2011 letters $b$ and c cannot transfer/rent their public housing ownership. Secondly, there is a legal gap for the parties that want to transfer public housing ownership at an uncontrolled price and transfer it to parties that are not classified as low-income families under the pretext of the absence of a transfer institution.

\section{Concept of Institution for Transfer of Public Housing Ownership for Low- Income Families}

Philosophically and ideologically, a development starts from the fundamental, namely, a concept. Each sector has a concept. Law in concepts always does not come out of its normative nature, and it contains values on justice, propriety, and others. According to Satjipto Rahardjo, the application of justice in society requires management, and it cannot be left for the community to manage it (Rahardjo, 2000). Therefore, the public housing transfer institution realizes intra-generation justice and inter-generation justice. Intra-generational justice strives for a fair distribution of and access to resources for all people of the same generation, with more focus on the needs of the disadvantaged in society. While inter-generation justice demands a fair distribution of spatial resources to allow all people at present and future generations to use those resources in order to meet their basic needs (Uwayezu \& de Vries, 2018).

The practice of public housing ownership for low-income family's institution has been commonly recognized and implemented in the United States of America; they called it the Community Land Trust (CLT) (Peterson, 1996). The first American CLT emerged in Albany, Georgia, during the late 1960s. Called "New Communities," the project held the concept of long-term, stable access to land at its core (Stein, 2013). The CLT model of ownership is increasingly being spoken of as a useful tool for providing genuinely affordable housing through land ownership reform (Moore, 2011).

Defining the CLT has become increasingly difficult in recent years because the term has come to characterize a variety of different models. The key feature of the CLT structure is the permanent transfer of land from the speculative market to a trust, which is typically control by a nonprofit organization for common benefits (DeFilippis, Stromberg, \& Williams, 2018), yet other CLTs are sponsored by local governments (Curtin \& Bocarsly, 2008).

The CLT holds land for what it conceives to be public interest while providing for the private use of land through lease contract (Meehan, 2014). Essentially, the ground lease is a contract between the CLT and the homeowner giving the homeowner exclusive access and rights to use the land but limiting those rights upon the resale of the houses (Curtin \& Bocarsly, 2008). By retaining control of the underlying land, the land trust can ensure that the homes are resold at affordable prices to the next buyer. This strategy retains the initial public investment in affordable housing and preserves the subsidy for the benefit of the next generation of homeowners (Towey, 2015). 
The land is owned permanently by the CLT, hence the name "land trust" (Gray, 2008). However, there is also CLT that is not technically a CLT at all, namely Chicago CLT. Rather than own land and dictate affordability through leases, the Chicago CLT instead ensures continued affordability through deed restrictions. The deed restrictions place limits on the income of the eligible buyers and resale price of subsidized homes. The Chicago CLT does not own land but manages and oversees the enforcement of these deed restrictions (Towey, 2015).

There are several claims of benefits of CLTs, which are (Gray, 2008):

1. Expanding access to homeownership, especially for low and moderateincome families in areas where market-rate homeownership is prohibitive;

2. Preserving access to homeownership by maintaining affordability over time, thereby keep housing affordable for generations of families;

3. Enhancing the security of tenure by offering first-time homeowners a chance to succeed;

4. Stabilizing neighborhoods by stabilizing property values, reducing the number of absentee landlords, and combating gentrification;

5. Creating personal wealth, albeit limited;

6. Preserving community wealth by attracting public subsidies and preventing privatization;

7. Building social capitals;

8. Promoting community development and diversity;

9. Enabling personal mobility to better employment and better neighborhoods. The CLT model is governed by a tripartite governance structure, in which residentmembers, local community, and broader expert-stakeholders have equal representation on the democratically elected governing board (Thompson, 2018).

As a stakeholder in the transfer of homeownership, the Government shall appoint or establish a public housing transfer institution for low-income families as mandated by Law No. 1/2011. In this case, it is more appropriate to establish a new institution that implements the transfer of ownership rather than appointing an institution, because, with the existence of institutions that specifically regulate the transfer of ownership, it is expected that the main functions and tasks can be carried out more optimal.

The organ of management of the transfer institution is tripartite or constitutes the unity of three parties, consisting of 1) government; 2) low-income family's representatives as homeowners; and 3) third party consisting of experts in the housing sector and public appraisers. The government acts as the party responsible for housing control through the formulation and policies decree and national strategies in the housing sector (Article 6 paragraph (1) Law No.1/2011). Second, the public participation (in this case is the involvement of low-income family's representatives as homeowners) is necessary for the government administrators to get to know their citizens' way of thinking and custom, the problems they face, means 


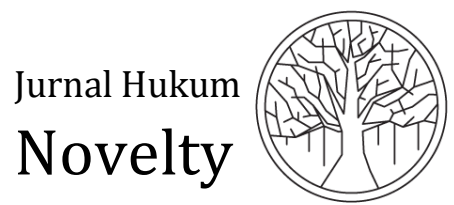

Volume 10, Issue 01, 2019, pp. 23-33

P-ISSN: 1412-6834

and solutions, and the contributions to solve the problems they face (Jati, 2012). Thus, it is expected that the implementation of the transfer of ownership of public housing will always prioritize the interest of low-income families. The last element, namely the public appraisal of the property, as one of the organs of the management has the responsibility to assess the land, house, and their equipment in the case of the resale of the low-income families' house.

Thus, the functions and tasks of the transfer of public housing institution are applied by modifying the concepts in CLT. First, the modifying concept of CLT is controlling the resale prices to create affordable public housing for low-income families. One of the main problems concerning the inability to acquire a house is the widening gap between stagnant incomes and the rising cost of homes (Firmansyah \& Indika, 2017). The houses that are intended for the low-income families should not be used as a speculative commodity by people who have more economic prospects or more ability in the future (The regulation of Minister of Human Settlement and Regional Infrastructure Number: 403/KPTS/M/2002). Therefore, the transfer institution must have the role to control the resale price of houses for low-income families.

Since in Indonesia, there are no provisions regarding the formula for controlling land prices, the concept used by CLT is suitable to fill the gaps. The limitations on resale prices are usually established through formulas that allow the seller to recoup her original investment plus some amount of appreciation. Perhaps the most common formulas - generally known as "appraisal-based formulas" - limit the price to the original purchase price plus a specified percentage (e.g., 25 percent) of total market appreciation as determined by the difference between appraised value at the time of purchase and at the time of resale (Abramowitz \& White, 2006).

The second modifying is the buyer eligibility restrictions that focus on the income categories of the people permitted to buy a home when the owners want to sell it. The maximum incomes for eligible buyers are usually adjusted for household size by the Ministry of Public Works and People's Housing.

The other possible modification is assuring the direct use of public housing by the intended group for the intended purposes and preserving the quality of the land and improvements for future users. Members must live in the homes, thereby preventing absentee landlord problems, but may sell the home back to the CLT or low-income households (Gray, 2008). Other types of use restrictions include: 1) those that require proper maintenance; 2) prohibit uses that would diminish the quality of the homes for future residents or that would be detrimental to the surrounding community, 3) prohibit changes of function and utilization of public housing; 4) prohibit the transfer of infrastructure, facilities, and public utilities in a public housing environment.

Besides the above restrictions, it should be in there of what so-called as supervision. The proposed supervisions are two, that is preventive supervision and repressive supervision. The preventive supervision towards the transfer of public housing 
ownership for the low-income families, namely: 1) monitoring of compliance with technical standards for transferring public housing ownership to the low-income families; 2) periodic checks to ensure that the public housing is only owned and occupied by the low-income families. Monitoring of the suitability of the technical standards for transferring public housing ownership to the low-income families can be conducted through the role of the low-income families as a facilitator in transferring public housing ownership, while periodic checks can be done by executing regular surveys.

Repressive supervision is a supervision that is done after certain sanctionable conduct occurs, expecting that the violation by low-income families does not reoccur. In this case, law enforcement in transferring public housing ownership for lowincome families in Indonesia is performed by law enforcement officials. Thus, law enforcement officials may take action against anyone who rents or transfers ownership of public housing as referred to in Article 135 Law No.1/2011.

The transfer institution may impose administrative sanctions as stipulated in Article 50 paragraph (2) of the Law No.1/2011 against violations of the Article 135 in the law a quo, by imposing sanctions in the form of 1) temporary or permanent termination on construction work; 2) temporary control by the government (sealed); 3) freezing/revocation of the proof of ownership of the house; and 4) administrative sanctions.

Article 152 of the Law No.1/2011 explains the criminal provisions for violations of Article 135, namely a fine of a maximum of Rp 50.000.000,00 (fifty million rupiahs). However, concerning the enforcement of criminal law, the transfer institution has the power to report every person who violates Article 135 of Law No.1/2011 to the authorities.

Based on the description above, the concept of ownership transfer institution for public housing based on the CLT is very suitable to be applied in Indonesia. This concept aims to create social justice to the low-income families both in the present and future through the availability of houses for low-income families that are always affordable.

\section{Conclusion}

The transfer of public housing ownership is regulated in Article 55 paragraph (1) Law No. 1/2011. However, the transfer of public housing ownership must be carried out by an institution appointed or established by the Government or Regional Government, which is further regulated by a Government Regulation. Until now, the Government Regulation, which is a follow-up to Article 55 paragraph (5) which mandates to regulate further related to the appointment and establishment of the institution, has not been formed yet. 
Jurnal Hukum

As a follow-up to Article 55 of the Law No. 1/2011, the institution for the transfer of public housing must be established by the Government through a Government Regulation as a means to provide affordable and sustainable housing for future generations of low-income families. The functions and tasks of the transfer institution of public housing can be applied by modifying the concepts in Community Land Trust. Furthermore, to realize intergenerational justice, the transfer institution must conduct these following duties: 1) controlling the resale price; 2) buyer eligibility provisions; 3) occupancy and use restrictions; 4) preventive supervision; and 5) repressive supervision.

\section{References}

Abramowitz, D., \& White, K. (2006). Deed Restrictions and Community Land Trust Ground Leases; Two Methods of Establishing Affordable Home Ownership Restrictions. Housing News Network, 327-334. Retrieved from http://www.flhousing.org/wp-content/uploads/2012/12/Deed-Restrictionsand-Community-Land-Trust-Ground-Leases.pdf

Arimurthy, A., \& Manaf, A. (2013). Kemitraan Pemerintah Daerah, Lembaga Lokal, dan Masyarakat Dalam Pemenuhan Kebutuhan Rumah Bagi Masyarakat Berpenghasilan Rendah. Jurnal Pembangunan Wilayah Dan Kota, 9(3), 307-316. https://doi.org/10.14710/pwk.v9i3.6542

Curtin, J. F., \& Bocarsly, L. (2008). CLTs: A Growing Trend in Affordable Home Ownership. Journal of Affordable Housing \& Community Development Law, 17(4).

DeFilippis, J., Stromberg, B., \& Williams, O. R. (2018). W(h)ither the community in community land trusts? Journal of Urban Affairs, 40(6), 755-769. https://doi.org/10.1080/07352166.2017.1361302

Direktorat Jenderal Anggaran Kementrian Keuangan. (2015). Peranan APABN Dalam Mengatasi Backlog Perumahan Bagi Masyarakat Berpenghasilan Rendah. Retrieved from http://www.anggaran.depkeu.go.id/content/Publikasi/Kajian dan Artikel/Kajian Peranan APBN Dalam Mengatasi Backlog Perumahan.pdf

Firmansyah, E. A., \& Indika, D. R. (2017). Kredit Pemilikan Rumah Syariah Tanpa Bank: Studi di Jawa Barat. Jurnal Manajemen Teori Dan Terapan, 10(3), 223. https://doi.org/10.20473/jmtt.v10i3.6541

Gray, K. (2008). Community Land Trusts in The United States. Journal of Community Practice, 16(1), 65-78. https://doi.org/10.1080/10705420801977999

Huang, Y. (2012). Low-Income Housing in Chinese Cities: Policies and Practices. China Quarterly, (212), 941-964. https://doi.org/10.1017/S0305741012001270

Indrati, M. F. (1998). Ilmu Perundang-Undangan, Dasar-Dasar dan Pembentukannya. Jakarta: Kanisius.

Jati, R. (2012). Partisipasi Masyarakat dalam Proses Pembentukan Undang-Undang yang Responsif. Rechts Vinding (Media Pembinaan Hukum Nasional), 1(10), 257275.

Leks, E. M., Adharinalti, Susetyo, D. S., Sakti, T., Natalia, L., Adinegara, M., ... Besturen, M. (2013). Analisis dan Evaluasi Peraturan Perundang-Undangan tentang Perumahan Rakyat. Retrieved from https://www.bphn.go.id/data/documents/analisis_dan_evaluasi_peraturan_pe rundang-undangan_tentang_perumahan_rakyat.pdf 
Meehan, J. (2014). Reinventing Real Estate: The Community Land Trust As a Social Invention in Affordable Housing. Journal of Applied Social Science, 8(2), 113-133. https://doi.org/10.1177/1936724413497480

Moore, T. (2011). Reviews: The Ways of The Community Land Trust. Journal of Built Environment, 37(1).

Motley, C. M., \& Perry, V. G. (2012). Living on the Other Side of the Tracks: An Investigation of Public Housing Stereotypes. Journal of Public Policy \& Marketing, 32(Special Issue), 48-58. https://doi.org/10.1509/jppm.12.029

Newman, S., \& Harkness, J. (2002). The Long-Term Effects of Public Housing on Children. Journal of Public Policy Analysis and Management, 21(1), 21-43.

Peterson, T. (1996). Community Land Trusts: An Introduction. Planning Commissioners Journal, 23(10), 9-12.

Rahardjo, S. (2000). Ilmu Hukum. Bandung: Citra Aditya Bhakti.

Soekanto, S., \& Mamudji, S. (2007). Penelitian Hukum Normatif Suatu Tinjauan Umum. Jakarta: Raja Grafindo Persada.

Stein, S. I. (2013). Wake Up Fannie, I Think I Got Something To Say To You: Financing Community Land Trust Homebuyers Without Stripping Affordability Provisions. Emory Law Journal, 60, 209-249.

Thompson, M. (2018). From Co-Ops to Community Land Trusts: Tracing the Historical Evolution and Policy Mobilities of Collaborative Housing Movements. Housing, Theory and Society, 1-19. https://doi.org/10.1080/14036096.2018.1517822

Tim Komunikasi Publik Ditjen Penyediaan Perumahan. (2016, October). Target Satu Juta Rumah. Maisona, 01, 08. Retrieved from http://perumahan.pu.go.id/source/Majalah Maisona/PDF/maisona1.pdf

Toros, H., \& Flaming, D. (2018). Prioritizing Homeless Assistance Using Predictive Algorithms: An Evidence-Based Approach. Cityscape: A Journal of Policy Development and Research, 20(1), 117-146. Retrieved from https://www.huduser.gov/portal/periodicals/cityscpe/vol20num1/ch6.pdf

Towey, M. (2015). The Land Trust Without Land: The Unusual Structure of the Chicago Community Land Trust. Journal of Affordable Housing, 18(3), 335-362.

Uwayezu, E., \& de Vries, W. (2018). Indicators for Measuring Spatial Justice and Land Tenure Security for Poor and Low-Income Urban Dwellers. Land, 7(3), 84. https://doi.org/10.3390/land7030084

Vale, L. J. (1995). Introduction: Public Housing Transformations - New Thinking about Old Projects. Journal of Architectural and Planning Research, 12(3).

Yudis. (2015). Banyak Kritik, Agung Podomoro Belajar dari Pengalaman Kalibata City. Retrieved February 25, 2018, from housingestate.id website: http://housingestate.id/read/2015/09/18/banyak-kritik-agung-podomorobelajar-dari-pengalaman-kalibata-city/ 